\title{
POSISI PEREMPUAN PADA TEKS WACANA SASTRA: PEMBACAAN ANALISIS WACANA KRITIS
}

\author{
Besse Herdiana \\ Universitas Cokroaminoto Palopo \\ J1. Latamacelling, Tompotika, Wara, Kota Palopo, Sulawesi Selatan, Indonesia \\ besse@uncp.ac.id
}

\begin{abstract}
Abstrak
Penelitian ini bertujuan mendeskripsikan posisi perempuan pada teks wacana sastra.Penelitian ini adalah deskripsi kualitatif. Sumber data dalam penelitian ini adalah novel Ronggeng Dukuh Paruk karya Ahmad Tohari dan novel Tarian Bumikarya Oka Rusmini. Pengumpulan data dilakukan dengan teknik observasi, studipustaka, dan pencatatan.Hasil penelitian menunjukkan bahwa pilihan kata yang digunakan pengarang laki-laki untuk menggambarkan posisi aktor perempuan dalam novel Ronggeng Dukuh Paruk cenderung memarginalkan perempuan dengan penggambaran yang buruk (negatif) dan aktor laki-laki digambarkan secara biasa saja.Peristiwa dibahasakan dengan pilihan kata penghalusan. Sementaraitu, pengarang perempuan dalam novel Tarian Bumi memberikanidentifikasipada perempuan dengan nama yang melekat dan digambarkan secara apa adanya dan aktor laki-laki digambarkan secara buruk. Peristiwa digambarkan dengan kosakata disfimisme.
\end{abstract}

Kata Kunci: posisi, wacana

\section{The Position of Women in Literature Text: Reading the Critical Discourse Analysis}

\begin{abstract}
This study aims to describe the position of women in the text of literary discourse. This research is a qualitative description. The data source in this study is the Ronggeng Dukuh Paruk novel by Ahmad Tohari and Tarian Bumi by Oka Rusmini. Data collection is done by observation, literature review, and recording techniques. The results showed that the choice of words used by male authors to describe the position of female actors in the Ronggeng Dukuh Paruk novel tended to marginalize women with bad (negative) portrayals and male actors were portrayed as ordinary. The event is fulfilled with the choice of refining words. While female authors in the Tarian Bumi novel provide identification to women with names that are inherent and described as they are and male actors are portrayed poorly. The event is described by the word dysphemism..
\end{abstract}

Keywords: position, discourse

\section{PENDAHULUAN}

Bahasa merupakan medium pertarungan melalui berbagai kelompok dan kelas sosial yang berusaha menanamkan keyakinan dan pemahaman. Kenyataan tersebut menunjukkan bahwa ada peluang individu ataupun kelompok yang kuat untuk melakukan penetrasi terhadap kelompok lain. Salah satunya adalah posisi perempuan yang selalu termarjinalkan.
Bahasa dimaknai sebagai sesuatu yang tidak hanya seputar persoalan gramatika dan leksikal saja, tetapi membawa ideologi dan muatan kekuasaan.

Isu praktik kekuasaan baik itu seputar subordinasi dan dominasi yang berujung pada ketidaksetaraan sosial khususnya bagaimana menampilkan perempuan dalam teks seperti yang telah dipaparkan di atas dapat dijumpai pada 
media iklan, berita, dan wacana sastra. Wacana sastra dapat diartikan sebagai bentuk fiksasi yang menggambarkan fenomena-fenomena sisi kehidupan manusia dengan lingkungan sosialnya. Pengarang pada dasarnya menuangkan gagasannya berdasarkan pengalaman mengenai kehidupan masyarakat dalam kurun waktu dan situasi budaya tertentu. Termasuk di dalamnya peran dan posisi laki-laki dan perempuan dalam masyarakat. Perbedaan peran ini mengakibatkan hadirnya bentuk dominasi dan subordinasi laki-laki terhadap perempuan.

Bahasa, jika ditinjau dari sudut pandang wacana kritis tidak hanya berperan sebagai tindak komunikasi, yang hanya melibatkan bagaimana proses interaksi terjadi antara sesama individu, tetapi juga sebagai praktik sosial. Hal ini berarti bahwa bahasa adalah medium perantara bagaimana seseorang atau kelompok ditampilkan atau didefinisikan. Kenyataan tersebut menunjukkan bahwa ada peluang individu ataupun kelompok yang kuat untuk melakukan penetrasi terhadap kelompok lain.Salah satunya adalah posisi perempuan yang selalu termarjinalkan. Bahasa dimaknai sebagai sesuatu yang tidak hanya seputar persoalan gramatika dan leksikal saja, tetapi membawa ideologi dan muatan kekuasaaan.

Wacana sastra cenderung menempatkan posisi perempuan dari dua sudut pandang yang berbeda, pengarang laki-laki mewacanakan perempuan dan pengarang perempuan mewacanakan dirinya sebagai pihak yang harus dibela juga sebagai korban yang selalu diimbau untuk mendapatkan perhatian. Wacana sastra khususnya novel merupakan bentuk pertunjukan kebahasaan seorang pengarang. Dalam dunia sastra, secara umum dipahami bahwa tujuan penggunaan bahasa adalah untuk menimbulkan kesan estetik. Kadang kala istilah estetik menjebak pada konsep pemahaman bahwa efek penggunaan bahasa dalam karya sastra untuk keindahan, satu hal yang kadang luput dari perhatian bahwa bahasa sastra bukan hanya persoalan estetik, tetapi juga berkaitan dengan praktik tertentu yaitu praktik kekuasaan. Praktik kekuasaan laki-laki atas perempuan bekerja melalui bahasa.Kadangkala realitas digambarkan secara buruk. Perempuan kadangkala ditampilkan dengan citra yang negatif.

Sejumlah gagasan di atas menegaskan bahwa ada perbedaan wacana yang dilakukan oleh pengarang laki-laki dan perempuan, dalam menempatkan posisi perempuan dalam teks, sehingga menarik untuk ditelaah dan dianalisis secara mendalam. Adapun masalah yang akan dikaji dalam penelitian ini adalah posisi perempuan pada wacana sastra novel Ronggeng Dukuh Paruk dan Tarian Bumi.

Penelitian dengan topik perempuan dalam sastra banyak dilakukan dengan pendekatan feminisme, salah satunya penelitian yang dilakukan oleh (Amelia, 2009) dengan topik ideologi feminisme dari pengarang perempuan. Penelitian ini memiliki objek yang sama dengan pendekatan berbeda. Penelitian ini lebih berfokus pada kacamata analisis wacana kritis. Penelitian yang sama tentang AWK pada teks sastra pernah dilakukan oleh (Hwia, 2010) dengan objek sastra yang yang berbeda yakni teks drama. Penelitian ini menunjukkan bahwa ideologi terbentuk pada percakapan dengan melihat siapa yang lebih dominan memegang kendali dalam interaksi. Penelitian tentang kajian teks wacana juga pernah dilakukan oleh Padmadewi (2007) dengan judul 
Besse Herdiana: Posisi Perempuan pada Teks Wacana Sastra: Pembacaan Analisis Wacana Kritis

pengalihan topik dalam percakapan dengan menggunakan kajian analisis wacana. Pada penelitian ini Padmadewi hanya berfokus pada analisis wacana tanpa menghubungkan dengan kognisi sosial seperti halnya yang menjadi fokus dalam AWK.

\section{TEORI}

Setiap pengarang dalam menuangkan gagasannya ke dalam bentuk karya sastra memiliki ciri khas bahasa yang berbeda, hal yang senada dikemukakan oleh (Teeuw, 2003) bahwa bahasa sastra memiliki bahasa yang khas, dianggap bahasa yang spesial yang hanya dimanfaatkan oleh para pengarang (penyair). Pemakaian bahasa itu dianggap menyimpang dari bahasa sehari-hari dan bahasa yang normal (Teeuw, 70).

Untuk memperoleh efektivitas pengungkapan, bahasa dalam sastra disiasati, dimanipulasi, sehingga tampil dengan sosok yang berbeda dengan bahasa nonsastra (Nurgiyantoro, 2007). Bentuk struktur dari sebuah karya sastra (novel) dan segala sesuatu yang dikomunikasikan senantiasa dikontrol langsung oleh manipulasi bahasa pengarang (Nurgiyantoro, 2007).

Pemanfaatan teori analisis wacana kritis (AWK) pada wacana sastra didasarkan pada pandangan bahwa wacana sastra dapat dipandang sebagai wacana. AWK mempelajari tentang dominasi suatu ideologi serta ketidakadilan dijalankan dan dioperasikan melalui wacana (Darma, 2009)

Analisis wacana kritis melihat wacana sastra sebagai bentuk dan praktik sosial.Penggambaran wacana sebagai praktik sosial menyebabkan sebuah hubungan dialektis antara peristiwa diskursif tertentu dengan situasi tertentu, dan struktur sosial yang membentuknya. Praktik wacana menampilkan efek ideologi (Fairclough dalam Darma, 2009)

Penelitian tentang ideologi dalam sebuah teks khususnya dari sudut pandang AWK pernah dilakukan oleh (Hwia, 2010). Hasil penelitian menunjukkan bahwa bentuk ideologi dalam teks terjadi dalam interaksi percakapan dalam hal ini siapa yang memegang kendali interaksional, termasuk dalam menentukan tema atau topik pembicaraan.

Seorang pengarang menciptakan konstruksi sosial atas realitas, peristiwa, atau pengalaman hidup dan kehidupan manusia dengan membangun atau menciptakan dunia kehidupan di dalam karyanya. Dengan membangun dan menciptakan dunia kehidupan dalam karyanya, pengarang dengan leluasa dapat mengembangkan berbagai kemungkinan penafsiran realitas, peristiwa, atau pengalaman hidup yang diwujudkan dalam cerita.Karya sastra yang merupakan sebuah wacana, bebas dikritik dari berbagai sudut pandang AWK.

Analisis wacana kritis dipelopori oleh para pemikir intelektual seperti, Michel Focault, Antonio Gramsci, Sekolah Frankfrut, dan Louis Althusser.Gramsci berperan terutama dengan teorinya mengenai hegemoni yaitu bagaimana wacana yang dikembangkan mampu memengaruhi khalayak, bukan dengan kekerasan melainkan secara halus dan diterima sebagai suatu kebenaran.Althusser dengan teori ideologi melihat ideologi sebagai praktik pemosisian seseorang dalam posisi tertentu dalam hubungan sosialnya.

Menurut (Wodak, 2001), "Critical Discourse Analysis (CDA) takes an interest in the ways in which 
linguistic forms are used in various expression and manipulation of power. Power is signalled not only by grammatical forms within a text, but also by a person control of a social occasion by means of the genre of a text. It is often exactly within the genres associated with given social occasions that power is exercised or challenged"

Pendapat Wodak tersebut menjelaskan bahwa analisis wacana kritis menekankan pada bentuk penggunaan bahasa dalam berbagai dimensi, salah satunya yaitu dengan dimensi kekuasaan. Melalui penggunaan bahasa kekuasaan dapat dimanipulasi. Praktik kekuasaan tidak hanya bekerja melalui penggunaan gramatikal teks, tetapi melalui kontrol dalam suatu praktik sosial dengan cara genre yang berhubungan dengan praktikpraktik lain.

Wacana dari sudut pandang analisis wacana kritis merupakan bentuk praktik sosial yang menyusun dunia sosial dan disusun oleh praktik-praktik sosial yang lain. Sebagai praktik sosial, wacana berada dalam hubungan dialektik dengan dimensidimensi sosial yang lain. Wacana tidak hanya memberikan kontribusi pada pembentukan dan pembentukan kembali struktur sosial namun merefleksikan pembentukan dan pembentukan kembali struktur sosial tersebut (Jorgensen, 2010)

$$
\text { Lebih lanjut menurut }
$$

Jorgensen(2010), analisis wacana kritis bersifat "kritis" maksudnya adalah bahwa analisis ini bertujuan mengungkap peran praktik kewacanaan dalam upaya melestarikan dunia sosial, termasuk hubungan-hubungan sosial yang melibatkan hubungan kekuasaan yang tidak sepadan. Dengan demikian, tujuannya agar bisa memberi konstribusi kepada perubahan sosial disepanjang garis hubungan kekuasaan dalam proses komunikasi dalam masyarakat secara umum.

Apa yang dimaksudkan oleh Jorgensen dengan hubungan kekuasaan yang tidak sepadan dalam proses komunikasi tampak tercermin pada komunikasi dunia digital khususnya pemberitaan perempuan dalam media. Hal ini berdasar pada pada temuan hasil riset (Setyorini, 2017) pada artikelnya yang berjudul "Analisis Wacana Kritis Pemberitaan Perempuan di Media Sosial. Setyorini menjelaskan bahwa bentuk kuasa/kekuasaan bekerja melalui komentar kasar, komentar seks, argumen yang memberikan stigma tentang perempuan, memarginalkan perempuan dan penyebaran kebencian.

Analisis wacana kritis pada dasarnya memandang bahasa sebagai bagian dari kekuasaan, terutama dalam membentuk subjek serta berbagai tindakan representasi yang terdapat di dalam masyarakat, sehingga analisis wacana kritis tidak hanya dilihat dari aspek kebahasaan, tetapi menghubungkannya dengan konteks. Konteks yang dimaksud di sini adalah tujuan dan praktik-praktik tertentu (Badara, 2013)

Hal yang senada dipaparkan Fairclough dan Wodak (Eriyanto, 2009) bahwa analisis wacana kritis melihat wacana sebagai pemakaian bahasa dalam tuturan dan tulisan sebagai bagian dari praktik sosial. Praktik wacana bisa jadi menampilkan efek ideologi yang memproduksi dan mereproduksi hubungan kekuasaan yang tidak seimbang antara kelas sosial, laki-laki dan wanita, kelompok mayoritas dan minoritas tempat perbedaan itu direpresentasikan dalam posisi sosial yang ditampilkan. 
Besse Herdiana: Posisi Perempuan pada Teks Wacana Sastra: Pembacaan Analisis Wacana Kritis

Lebih lanjut dikemukakan Fairlough dan Wodak (Eriyanto, 2009:7), analisis wacana kritis melihat bahasa sebagai faktor penting, yaitu bagaimana bahasa digunakan untuk melihat ketimpangan kekuasaan dalam masyarakat dengan kata lain analisis wacana kritis menyelidiki bagaimana melalui bahasa kelompok sosial yang ada saling bertarung dan mengajukan versinya masing-masing. Seperti yang dikemukakan (Wodak, 2001):

"Power is about relations of difference, and particularly about the effects of differences in social structures. the constant unity of languange and other social matters ensures that languange is entwined in social power in a number of ways: language indexes power,expresses power, is involved where there is contention over and challenge to power. Power does not derive from language, but language can be used to challenge power. Languange provides a finely articulated means for differences in power in social hierarchical structures"

Pendapat Wodak di atas mengindikasikan bahwa kekuasaan merupakan bentuk hubungan yang mengatur tentang perbedaan, terutama efek dari perbedaan struktur sosial.Bahasa merupakan kesatuan sosial yang mampu mengungkapkan pertentangan dari sebuah kekuasaan.Kekuasaan tidak berasal dari bahasa, tetapi bahasa dapat digunakan untuk mengungkapkan kekuasaan dalam hal ini bahasa sebagai sarana/ medium pengungkapan bentuk kekuasaan dalam struktur sosial.

Analisis wacana kritis (AWK) adalah sebuah upaya atau proses (penguraian) untuk memberi penjelasan dari sebuah teks (realitas sosial) yang mau atau sedang dikaji oleh seseorang atau kelompok dominan yang kecenderungannya mempunyai tujuan tertentu untuk memperoleh apayang diinginkan. Artinya, dalam sebuah konteks harus disadari akan adanya kepentingan (Darma, 2009:49)

Analisis wacana kritis digunakan untuk mendeskripsikan sesuatu, menerjemahkan, menganalisis, dan mengkritik kehidupan sosial yang tercermin dalam teks atau ucapan. Analisis ini berhubungan dengan studi analisis teks serta ucapan untuk menunjukkan sumber diskursif, yaitu kekuasaan, ketidaksetaraan, ketidakadilan, dan prasangka. Analisis wacana kritis diasosiasikan, dipertahankan, dilembagakan, dan ditransformasikan dalam kehidupan sosial, ekonomi, politik, dan konteks sejarah yang spesifik.

Hubungan yang kompleks antara bahasa dan fakta sosial akan menampilkan efek ideologi yang kadang tidak jelas dan tersembunyi dalam penggunaan bahasa maupun pengaruh relasi kekuasaan. Dalam wacana ideologi diekspresikan namun kadang tidak dipertanyakan dan dianalisis, dengan demikian analisis wacana kritis memiliki tugas untuk menjelaskan hal-hal tersebut dengan analisis yang teliti dan terinci (Titscher, 2009).

\section{METODE}

Metode yang digunakan dalam penelitian ini adalah metode deskriptif yakni mendeskripsikan secara sistematis dan akurat mengenai data, sifat-sifat atau hubungan fenomena-fenomena yang diteliti dengan menggunakan metode deskriptif. Dengan metode deskriptif akan didapatkan deskripsi data secara alamiah. Langkah selanjutnya adalah melakukan pengumpulan data dengan cara pencatatan, penelaahan data, pengklasifikasian data, penganalisaan data, dan penyimpulan data. 
Sumber data dalam penelitian ini berjumlah dua novel yang ditulis oleh pengarang laki-laki dan pengarang perempuan. Kedua novel tersebut adalah:

1. Tarian Bumi Karya Oka Rusmini,

2. Ronggeng Dukuh Paruk karya Ahmad Tohari.

Bentuk analisis ditekankan pada pengungkapan pesan-pesan yang tampak dengan menghubungkannya dengan konteks sebagai isi makna yang tersembunyi dalam teks.Data yang telah dikumpulkan diolah dan dianalisis melalui beberapa tahapan yang merupakan suatu kesatuan yang berurutan. Tahapan-tahapan analisis data dalam penelitian ini dilakukan melalui prosedur sebagi berikut:

1. mengidentifikasi data yang menunjukkan pilihan kata yang digunakan untuk menggambarkan aktor dan peristiwa dengan cara:

a. melihat pilihan kata yang digunakan untuk menggambarkan aktor lakilaki,

b. melihat pilihan kata yang digunakan untuk menggambarkan aktor perempuan, dan

c. melihat pilihan kata yang digunakan untuk menggambarkan peristiwa.

2. klasifikasi,

3. analisis, dan

4. menarik kesimpulan.

\section{HASIL DAN PEMBAHASAN}

Pada bagian ini, diuraikan hasil penelitian terhadap analisis dalam novel Ronggeng Dukuh Paruk karya Ahmad Tohari dan novel Tarian Bumi karya Oka Rusmini.Uraian hasil penelitian terdiri atas dua bagian. Bagian pertama merupakan bukti yang diperoleh dari hasil analisis data yang dilengkapi dengan kutipan teks. Bagian kedua merupakan pembahasan terhadap hasil penelitian.

\section{Pilihan kata/ leksikal (kosakata)}

Pilihan kata berhubungan dengan kosakata yang dipakai pengarang untuk menggambarkan aktor beserta dengan peristiwanya.Pilihan kata ini berimplikasi pada dua hal yaitu; (1) untuk melihat makna yang ingin dikomunikasikan kepada pembaca, (2) pihak atau kelompok mana yang dirugikan dengan penggunaan kata tersebut.

a. Ronggeng Dukuh Paruk (RDP)

1) Pilihan kata yang digunakan untuk menggambarkan aktor

Secara umum dengan melihat pilihan kata yang digunakan aktor perempuan ditempatkan dalam posisi marginal. Pilihan kata yang digunakan antara lain: penagih berahi, perawan kencur, barang bagus, ramah terhadap semua laki-laki, mempesona, masih segar, perempuan milik umum, perempuan jajanan. Pilihan kata tersebut dapat dilihat pada beberapa kutipan di bawah ini:

(1) "Mimik penagih birahi yang selalu ditampilkan oleh seorang ronggeng" (Tohari, 2011:13)

(2) "Seorang perawan kencur yang terbaring di dalamnya"(Tohari, 2011:57)

(3) "Masalahnya, Srintil yang sampean kehendaki masih kekanak-kanakan. Ah sampean jangan lupa, Srintil masih demikian hijau.Maka siapapun yang menghendaki kesegarannya harus sedikit bersabar.Dengar,Pak. Srintil masih segar seperti kecambah,"sambung Nyai Kartareja" (Tohari, 2011)

Kosakata penagih berahi digunakan untuk menggambarkan aktor perempuan yaitu gambaran umum seorang ronggeng. Kosakata berahi penagih secara halus dapat diartikan penggoda selanjutnya pada kalimat (2) perawan kencur digunakan sebagai label yang melekat pada diri Srintil, yang berarti seorang remaja yang 
baru bertumbuh, tidak tahu akan apa-apa hal-hal yang berbau dewasa, dengan identifikasi yang seperti itu menunjukkan bahwa Srintil tidak akan menolak laki-laki siapapun yang menghampirinya dalam kelambu, ditambah lagi dengan keterangan penjelas yang terbaring didalamnya menandakan Srintil sebagai sosok yang ditampilkan dalam teks sebagai seorang perempuan sepenuhnya memiliki jiwa kepasrahan tanpa penolakan apapun, termasuk menjalani kehidupannya sebagai seorang ronggeng. Kalimat (3) masih kekanak-kanakan, masih hijau adalah pilihan kata yang mengasosiasikan bahwa Srintil masih terlalu muda, masih segarsegarnya untuk dinikmati bagi laki-laki yang menghendakinya.

Data:

(4) "Dalam waktu semalam, Srintil akan menjadi barang yang sudah terbeli"(Tohari, 2011:60)

(5) "Bukan main!Pak Bajus tidak akan percaya di daerah ini ada barang bagus(Tohari, 2011:309)

Pada kutipan teks di atas (4), (5) aktor perempuan diibaratkan sebagai barang, yang mengacu pada makna sesuatu yang diperjual-belikan. Sehingga perempuan identik denganbarang yang bisa diperjualbelikan.Begitupun dengan penggalan kalimat kedua, "Pak Bajus tidak akan percaya di daerah ini ada barang bagus". Kosakata barang bagus mengacu pada penggambaran aktor perempuan, sementara Pak Bajus sebagai aktor lakilaki tidak didefinisikan atau digambarkan. Dengan memberi penamaan barang bagus secara tidak langsung mengasosiasikan bahwa perempuan setara dengan barang, yang bisa dimiliki oleh siapa saja bagi mereka yang berduit.

Data:
(6) "Emak sebagai perempuan yang selalu ramah terhadap laki-laki, yang tak pernah menepis tangan laki-laki yang menggerayanginya."

Emak (aktor perempuan) digambarkan sebagai sosok perempuan yang memiliki karakter ramah terhadap laki-laki siapa saja. Pilihan kata ramah terhadap laki-laki memberikan gambaran seorang perempuan yang cenderung sebagai penggoda dengan sikapnya yang meladeni semua laki-laki.Hal ini dipertegas dengan penggalan kalimat "tak pernah menepis tangan laki-laki yang menggerayanginya". Secara struktur kalimat tersebut menempatkan laki-laki sebagai pelaku perbuatan dan aktor perempuan sebagai korban ditandai dengan kosakata menggerayangi. Akan tetapi penggalan kalimat sebelumnya "tak pernah menepis tangan laki-laki" menjelaskan bahwa aktor perempuan tidak menolak perbuatan aktor laki-laki yang menggerayanginya.

Data:

(7) "Kemudian Srintil sendiri merasakan kepahitan sejarah hidup yang ditempuhnya sebagai perempuan milik umum"(Tohari, 2011:337)

(8) "Aku terkesan oleh citra pada wajahnya. Wajah perempuan jajanan yang sangat berhasrat menjadi ibu rumah tangga, Jus! "(Tohari, 2011:385) Selanjutnya pilihan kata perempuan milik umum pada kalimat (5) digunakan untuk menggambarkan keterangan aktor tokoh Srintil. Perempuan milik umum artinya perempuan milik semua orang, siapapun berhak untuk memakai dan memilikinya. Pilihan kata perempuan milik umum secara tidak langsung menempatkan perempuan pada posisi 
marginal dengan menggambarkannya secara buruk atau dengan kesan negatif. Begitupun dengan penggalan kalimat (6) perempuan jajanan yang memberikan makna kalau perempuan tidak lebih dari tempat jajan bagi laki-laki.Aktor perempuan dijadikan sebagai objek penceritaan.

2) Pilihan kata yang digunakan untuk menggambarkan aktor laki-laki.

Kutipan data di atas menggambarkan aktor laki-laki dibahasakan oleh pengarang laki-laki.Aktor laki-laki digambarkan dengan penamaan saja tanpa memberikan istilah yang mengarah kepada pemaknaan yang buruk atau negatif.Pak Bajus, lakilaki, aku, mantri, Pak Marsusi adalah penamaan yang diberikan kepada aktor laki-laki. Pilihan kata tersebut dapat dilihat pada beberapa kutipan data di bawah ini:

(1) "masalahnya Srintil yang sampean kehendaki masih kekanak-kanakan. Ah sampean jangan lupa, Srintil masih demikian hijau. Maka siapapun yang menghendaki kesegarannya harus sedikit bersabar. Dengar, Pak. Srintil masih segar seperti kecambah, "sambung Nyai Kertareja.(Tohari, 2011:125)

(2) "kau layani Pak Marsusi karena semua orang tahu kau seorang ronggeng dan sundal" (Tohari, 2011:152)

Pada kutipan data di atas (1), (2) aktor laki-laki hanya dibahasakan dengan penamaansaja yaitu kata Pak dan Pak Marsusi. Hal yang berbeda dengan aktor perempuanyang diberikan penamaan tertentu yang mengarah pada citraan yang negatif. Seperti pada data (1) aktor perempuan Srintil digambarkan seperti kecambah, masih hijau dan kekanakkanakan. Begitupun dengan data (2) aktor laki-laki hanya diberikan penamaan saja berbeda dengan aktor perempuan yang digambarkan dengan identifikasi sundal. Hal yang hampir sama pada kutipan data di bawah ini:

(3) "Bukan main! Pak Bajus tidak akan percaya di daerah ini ada barang bagus" (Tohari, 2011:309)

(4) "Srintil tidur bersama laki-laki sama menjijikkannya dengan membayangkan emak melarikan diri bersama mantri itu" (Tohari, 2011:53)

Pada kutipan data di atas aktor laki-laki diidentfikasidengan nama Pak Bajus dan Mantri tanpa diberikan penjelasan mengenai keterangan aktor. Sementara aktor perempuan di identifikasi dengan pilihan kata barang bagus. Identifikasi yang demikian memberikan gambaran bahwa pengarang laki-laki berusaha memberikan citraan yang positif kepada aktor laki dengan tidak menyebutkan betapa mereka tergoda dengan melihat perempuan yang diasosiasikan dengan istilah barang bagus.

\section{b. Tarian Bumi (TB)}

1) Pilihan kata yang digunakan menggambarkan aktor perempuan

Pengarang perempuan dalam novel Tarian Bumi menggambarkan aktor perempuan secara berbeda ketika menggambarkan aktor laki-laki. Pilihan kata yang digunakan untuk menggambarkan aktor perempuan lemah lembut dan tidak suka mengeluh. Selain itu identifikasi yang diberikan hanya sebatas penamaan saja yaitu Telaga, Luh, Kenanga dan Perempuan. Seperti yang tampak dalam kutipan di bawah ini:

(1) Perempuan Bali itu Luh, perempuan yang tidak terbiasa mengeluarkan keluhan. Mereka lebih memilih berpeluh. Hanya dengan cara itu 
Besse Herdiana: Posisi Perempuan pada Teks Wacana Sastra: Pembacaan Analisis Wacana Kritis

mereka sadar dan tahu bahwa mereka masih hidup dan harus tetap hidup. Keringat mereka adalah api. Dari keringat itulah asap dapur bisa tetap terjaga. Mereka tidak hanya menyusui anak yang lahir dari tubuh mereka. Mereka pun menyusui hidup itu sendiri (Rusmini, 2007:25)

Perempuan diidentifikasi sebagai orang yang kuat ditandai dengan kalimat tidak terbiasa mengeluarkan keluhan, memiliki semangat yang tinggi, mampu bekerja dan menghidupi diri mereka sendiri. Seperti yang tampak dalam kutipan "dari keringat itulah asap dapur bisa tetap terjaga". Perempuan tidak digambarkan hanya mengurus persoalan anak saja tetapi bagaimana mereka mampu menghidupi diri mereka dari hasil jerih payah sendiri seperti yang tampak dalam penggalan kalimat, "Mereka tidak hanya menyusui anak yang lahir dari tubuh mereka. Mereka pun menyusui hidup itu sendiri”.

2) Pilihan kata yang digunakan untuk menggambarkan aktor laki-laki

Aktor laki-laki dibahasakan oleh pengarang perempuan. Aktor perempuan cenderung tidak terlalu diberikan penamaan sementara aktor laki-laki digambarkan dengan menggunakan beberapa pilihan kata yaitu; mata liar, idiot, tolol, binatang menjijikkan, wabah, tukang kawin.Seperti yang tampak pada beberapa kutipan di bawah ini:

(1) Mereka semua tertawa, mata mereka masih liar mengupas tubuh telaga(Rusmini, 2007:9)

(2) Ayahnya adalah laki-laki paling tolol. Ketololan laki-laki itu membuat telaga merasa bisa hidup tanpa laki-laki. Bagi telaga, dialah laki-laki idiot yang harus dipanggil dengan nama yang sangat agung, Aji, Ayah. Menjijikkan sekali. Lelaki yang tidak bisa bersikap. Laki-laki yang hanya bisa membanggakan kelelakiannya (Rusmini, 2007:10)

Aktor laki-laki oleh pengarang perempuan seperti pada kutipan (1) di atas digambarkan dengan pilihan kata bermataliar, yang artinya laki-laki yang memiliki mata jelalatan ketika melihat tubuh perempuan. Sementara aktor perempuan yang mengambil peran sebagi objek digambarkan secara apa adanya hal ini tergambar pada kalimat mata mereka masih liar mengupas tubuh telaga. Selain bermata liar aktor laki-laki juga diidentifikasi sebagai laki-laki tolol seperti yang tampak pada kutipan (2).Lelaki tolol, lelaki idiot adalah identifikasi yang digunakan oleh pengarang perempuan untuk menggambarkan aktor laki-laki yang tidak bisa bersikap layaknya seorang lakilaki.

(3) "Kenanga terdiam. Sejak dulu, dia memang sudah menduga laki-laki yang menitipkan benih dirahimnya adalah binatang menjijikkan. Laki-laki itu benar-benar memiliki ciri khas binatang ((Rusmini, 2007:83)

(4) “tidak mungkin, Meme!'Sadri berteriak

"kenapa?"

"harga diri Putu Sarma akan Jatuh!"

"harga diri?"

"ya, Meme."

"laki-laki sial itu masih memikirkan harga diri?"

"Meme jangan berkata seperti itu,Nanti Telaga dengar!" 
"Biar! Biar semua orang tahu kau memang kawin dengan wabah!" (Rusmini, 2007:161)

Dari kutipan percakapan di atas seperti yang tampak pada kutipan (3) dan (4) kosakata yang digunakan untuk menggambarkan aktor laki-laki seperti yang tampak pada kutipan di atas adalah binatang menjijikkan dan wabah. Binatang menjijikkan diasosiasikan dengan sifat laki-laki yang memiliki sifat seperti binatang. Pada kutipan (4) aktor ibu (meme) menyebutkan menantunya (putu sarma) dengan sebutan wabah. Wabah yang secara semantis dimaknai sebagai pengganggu hal ini mengindikasikan bahwa kehadiran aktor laki-laki (putu sarma) sebagai pengganggu kehidupan anaknya. Identifikasi yang lain oleh pengarang perempuan untuk menggambarkan aktor laki-laki tampak pada kutipan dibawah ini:

(5) "laki-laki yang memiliki ibu adalah laki-laki yang paling aneh, dia bisa berbulan-bulan tidak pulang. Kalau di rumah kerjanya hanya matajen, adu ayam, atau duduk-duduk dekat perempatan bersama para berandalan, minum tuak" (Rusmini, 2007:12)

Pada kutipan di atas aktor lakilaki digambarkan sebagai peminum, lakilaki yang hobinya hanya mengadu ayam.Identifikasi yang demikian oleh pengarang perempuan bertujuan untuk menegaskan bahwa aktor laki-laki adalah laki-laki yang tidak bertanggungjawab.

\section{b. Pembahasan}

Novel Tarian Bumi yang ditulis oleh pengarang perempuan, pilihan kata yang digunakan untuk menggambarkan aktor laki-laki cenderung buruk, aktor laki-laki diidentifikasi dengan pilihan kata mata liar, idiot, tolol, binatang menjijikkan, wabah, tukang kawin. Pilihan kata tersebut digunakan untuk menggambakan aktor laki-laki melalui deskripsi tingkah laku dan pemberian nama julukan, seperti pilihan kata tolol, idiot, tukang kawin, yang digunakan untuk menggambarkan karakter si aktor laki-laki. Wabah, binatang menjijikkan adalah pilihan kata yang digunakan untuk memberikan nama panggilan/julukan. Hal yang berbeda ketika pengarang perempuan memberikan identifikasi terhadap aktor perempuan. Pengarang perempuan memberikan identifikasi terhadap aktor perempuan sesuai dengan nama yang melekat, dan digambarkan sebagai apa adanya. Pengarang perempuan menggambarkan peristiwa dengan pilihan kata yang cenderung lebih kasar. Seperti kata mengupas dan melahap yang mengarah kepada pemaknaan perempuan menjadi korban.

Pada novel Ronggeng DukuhParuk, Ahmad Tohari menggambarkan aktor perempuan melalui tokoh Srintil yang mewakili sosok perempuan Jawa pada masanya.Dalam realitas dijelaskan bahwa Ahmad Tohari dalam menulis tidak pernah terlepas dari pengalaman kedesaannya.Hal ini sesuai dengan setting yang dipakai oleh Ahmad Tohari pada, yaitu di Banyumas, sebuah desa di Jawa dimana pada masa itu PKI lagi maraknya.Dalam Ronggeng Dukuh Paruk pun dikisahkan demikian, begitupun dengan dunia peronggengan yang tumbuh di masyarakat Jawa.

Ahmad Tohari menggambarkan
tokoh perempuan Srintil yang
menyandang gelar sebagai ronggeng
memang memiliki tugas melayani laki-laki,
hal ini sesuai dengan apa yang
dikemukakan oleh Yuliastuti (2011),
bahwa dalam sejarahnya Ronggeng telah
ada sejak 185 tahun yang lalu, hal ini


Besse Herdiana: Posisi Perempuan pada Teks Wacana Sastra: Pembacaan Analisis Wacana Kritis

tertulis dalam karya sastra jawa yang sangat terkenal yaitu Serat Centini. Ronggeng pada awalnya adalah bentuk pemujaan untuk kesuburan. Ronggeng memiliki tugas tidak hanya menari menemani penonton sambil berjoget tetapi menemani di tempat tidur sebagai tolak bala dan simbol kejantanan.Istilah mewisuda yang dipakai oleh Ahmad Tohari adalah semacam bentuk ritual yang harus dijalani seorang ronggeng.

Berdasarkan dari pandangan tersebut dapat diasumsikan bahwa yang dikisahkan oleh Ahmad Tohari adalah cerminan budaya ronggeng Jawa,sehingga penggambaran Ahmad Tohari pada tokoh perempuan Srintil yang suka merayu, yang menggoda, mencium, dan lain sebagainya identik dengan profesi yang dijalaninya sebagai seorang ronggeng yang keberadaannya memang untuk melayani laki-laki. Tokoh Srintil tidak memandang laki-laki sebagai pihak yang berkuasa.

Jika teks dihubungkan dengan konteks tempat lahirnya teks, dalam hal ini sejauh mana pengalaman sosial pengarang terefleksi pada karyanya. Dapat disimpulkan bahwa data linguistik dalam bentuk transitivitas yang memberikan definisi yang buruk pada aktor perempuan yang menurut Fowler sebagai salah bentuk praktik pemarginalanmenjadi terbantahkan, karena yang dituliskan Ahmad Tohari pada aktor perempuan Srintil adalah cerminan sosial budaya ronggeng Jawa terlepas dari aspek biologis Ahmad Tohari sebagai seorang laki-laki.

Sementara itu, dari sudut pandang pengarang perempuan pada novel Tarian Bumi, dilihat dari latar sosial Oka Rusmini dibesarkan maka tidak heran jika dia lebih banyak bercerita tentang perempuan dari sudut pandang budaya Bali. Kebencian
Oka pada laki-laki berawal ketika ayahnya meninggalkan ibu kandungnya dan menikah lagi dan bahkan karena kebencian yang mengakar Oka pernah memutuskan untuk tidak menikah.

Gambaran yang ada dalam dunia realitas Oka Rusmini tampaknya banyak tercermin dalam dunia fiksi yang diciptakannya. Oka Rusmini yang memiliki dendam pada laki-laki yang berawal dari perceraian orang tuanya dan telaga yang dihadirkan merasa bisa hidup tanpa laki-laki sebagai sosok yang kuat, melakukan perlawanan dan penolakan terhadap subordinasi laki-laki, hal ini tergambar dari beberapa peristiwa yang lebih menonjolkan letak kesalahan ada pada laki-laki melalui rangkaian kalimat yang menempatkan aktor laki-laki pada posisi subjek pelaku.

\section{PENUTUP}

Bentuk pilihan kata yang digunakan pengarang laki-laki untuk mengambarkan posisi perempuan dalam novel Ronggeng Dukuh Paruk cenderung menempatkan perempuan dalam posisi marginal. Tokoh perempuan digambarkan dengan pilihan kata yang mengarahkan perempuan dalam kondisi buruk (negatif) sementara laki-laki digambarkan secara biasa saja. Penggambaran pada aktor perempuan dilakukan melalui pemberian julukan atau panggilan dan deskripsi karakter tingkah laku aktor.Peristiwa digambarkan dengan penghalusan. Dalam novel Tarian Bumi yang ditulis oleh pengarang perempuan, pilihan kata yang digunakan untuk menggambarkan aktor laki-laki cenderung menggambarkan secara buruk melalui deskripsi tingkah laku dan penamaan diri secara negatif sementara aktor perempuan digambarkan sesuai 
dengan nama yang melekat, dan digambakan sebagai apa adanya. Pengarang perempuan menggambarkan peristiwa dengan pilihan kata yang cenderung lebih kasar.

\section{DAFTAR PUSTAKA}

Amelia, K. (2009). Ideologi Feminisme Dalam Karya Sastra Angkatan 1970 Dan Angkatan 2000(On line)http://achsan.staff.usu.ac.iddiaks es 24 Desember 2013

Badara, A. (2013). Analisis Wacana (Teori, Metode, dan Penerapannya pada Wacana Media). Jakarta: Kencana Prenada Media Group.

Darma, Y. A. (2009). Analisis Wacana Kritis. Bandung: Yrama Widya.

Eriyanto. (2009). Analisis Wacana (Pengantar Analisis Teks Media). Yogyakarta: LKiS Printing Cemerlang.

Hwia, G. (2010). Kendali Interaksional sebagai Cerminan Ideologi: Analisis Wacana Kritis Trilogi Drama Opera Kecoa. Jurnal Linguistik Indonesia. https://doi.org/10.1007/s13398-0140173-7.2

Jorgensen, M. (2010). Analisis Wacana (Teori dan Metode). Yogyakarta: Pustaka Pelajar.

Nurgiyantoro, B. (2007). Teori Pengkajian Fiksi. Yogyakarta: Gadjah Mada University Press.

Padmadewi, N. N. (2007).Pengalihan Topik dalam Percakapan Studi Kasus dalam Kajian Analisis Wacana. Makalah disajikan dalam Seminar Perdana Bahasa Ibu di Bali, Universitas Udayana Bali, 20-21 Februari 2007.

Rusmini, O. (2007). Tarian Bumi. Jakarta: Gramedia Pustaka Utama.

Setyorini. (2017). Perempuan dan Kejahatan Cyber Analisis Wacana Kritis Pemberitaan Perempuan di Media Sosial. In Anlmage Jurnal Studi Kultural. https://doi.org/10.6084/m9.figshare.5
212336

Teeuw, A. (2003). Sastra dan Ilmu Sastra. Jakarta: Dunia Pustaka Jaya.

Titscher, S. (2009). ). Metode Analisis Teks dan Wacana. Terjemahan Gazali dkk. Yogyakarta: Pustaka Pelajar.

Tohari, A. (2011). Ronggeng Dukuh Paruk. Jakarta: Gramedia Pustaka Utama.

Wodak, R. (2001). Methods of Critical Discourse Analysis. London: SAGE Publiction. 
Besse Herdiana: Posisi Perempuan pada Teks Wacana Sastra: Pembacaan Analisis Wacana Kritis 